\title{
Family Burden of Narcotics Abusers Experiencing Relapse and Factors Exacerbating It
}

\author{
Rico Januar Sitorus ${ }^{1, *}$, Novrikasari ${ }^{2}$, and Imelda G. Purba ${ }^{2}$ \\ ${ }^{1}$ Lecturer in the Department of Epidemiology Faculty of Public Health Universitas Sriwijaya \\ ${ }^{2}$ Lecturers in the Department of Occupational and Environmental Health Faculty of Public Health \\ Universitas Sriwijaya.
}

\begin{abstract}
Background: Narcotics addicts must undergo rehabilitation to get recovery. During the recovery process, families bear both economic and social burdens. This study aimed to find out how the burden of families with family members who experienced relapse was and what factors could exacerbate it. This study used crosssectional study design by measuring family burden as an outcome. The samples in this study were 168 families having family members who abused narcotics and experienced relapse. Multivariate analysis with multiple linear regression showed that the factors exacerbating the family burden of narcotics abusers were the family member's age of first use of narcotics and drinking habits (dominant factor) with $\mathrm{R}=0.964$, $\mathrm{R}$ Square $=$ 0.929 , Adjusted R Square $=0.928$ and Durbin Watson $=0.982$. Narcotics abusers who experience relapse will increase the family burden. Factors that aggravate the family burden are as follows: first time using narcotics at an early age and alcohol drinking habit. Therefore, we must prevent the use of narcotics as early as possible among the entire community and stop drinking alcohol.
\end{abstract}

\section{Introduction}

The prevalence of narcotics abusers with heavy addiction in Indonesia is about $3.4-6.6$ $\%$.[1] The types of narcotics widely used are multiple substances with the proportion of about $47.92 \%$, shabu-shabu (crystal methamphetamine) of about $31.03 \%$ and ecstasy $15.69 \%$. [2].

Family conflicts and poor family relationships are the factors that can cause someone to abuse narcotics. [3] Family attitudes toward narcotics users are associated with the substance abuse such as tobacco, alcohol and narcotics. [4] Families (parents) addicted to narcotics also have a greater risk of their children abusing narcotics than those who are not. [5]

Narcotics addiction is a serious problem commonly found in narcotics abusers and this will be a family burden. It deals with a variety of issues, which can affect physical and mental health. [6] Research has shown that there is a clear biological difference between people's brains with addictive problems and people's brains with no addictive problems. The research results of Ma et al, 2011revealed that drug addicts resulted in abnormal brain function and structure. Changes in the brain also occur in people who are not addicted to heroin anymore. [7,8]. The social impact of narcotics abuse is so complex that so many countries in the world have determined that the use of narcotics is a criminal offense [9]. 
Narcotics addicts should be physically and psychologically rehabilitated with a population health approach, including their cultural and spiritual considerations such as therapeutic communities [10]. A therapeutic community is one form of therapy for narcotics addicts. This therapy increases the confidence of the addicts, positive perceptions, decreased crime rates in the community and positive relationships with partners in everyday life.[11,12]. This therapy is a nafa-free environment. Patients suffering from drug use disorders live together in an organized and structured environment to make change and the possibility of patients not to relapse despite being in the external environment. [13] Factors that cause relapse are lack of family support and loneliness [14]. Other risk factors that make a user reuse narcotics are negative stigma in society, feelings of depression, and rejection from family and the environment $[1,15,16]$. Reusing narcotics will degrade the quality of health and the psychological effect is that it will add to the burden of families both socially and economically $[17,18]$. This study wanted to find out how the burden of families who experienced relapse was and what factors could exacerbate it.

\section{Materials and Methods}

This study used cross-sectional study design. The population in this study was all families who had family members as narcotics abusers in Palembang City. The samples in this study were 168 families who had family members abusing narcotics and experiencing relapse. The samples were taken using purposive sampling technique, when a family member (husband, wife or parent) accompanied the respondent (inpatient or outpatient) to undergo treatment at a narcotics hospital (Ernaldi Bahar Hospital). The family member measured was the wife if the relapse was the husband or vice versa, and parents if the respondent was unmarried and lived with his/her parents. Two instruments, a structured questionnaire and the Caregiver Strain Index Instrument, were used in this study [19]. The structured questionnaire was used to find out the demographic features and independent variables, while the Caregiver Strain Index instrument was used to measure the family burden. The data were analyzed using Spearman correlation test and multiple linear regressions.

\section{Results and Discussions}

The majority of respondents interviewed in this study was the parents of the respondents $(66.07 \%)$ with high school education level (43.5\%), and employed (70.8\%). (Table 1) The proportion of respondents were as follows: sleep is disturbed $(93.5 \%)$, caregiving is inconvenient $(90.5 \%)$, caregiving is a physical strain $(89.9 \%)$, caregiving is confining (72 $\%)$, there have been family adjustments $(32.7 \%)$, there have been other demands on my time $(56.5 \%)$, there have been emotional adjustments $(56 \%)$, some behavior is upsetting $(77.4 \%)$, It is upsetting to find the person I care for has changed so much $(82.1 \%)$, there have been work adjustments $(61.9 \%)$, care giving is a financial strain $(87.5 \%)$, I feel completely over whelmed (89.9\%)

Based on the correlation test, the habit of drinking alcohol correlated positively and strongly $(r=0.956 ; p$ value $=0.0001)$, the age of initial narcotics use correlated positively and strongly correlated $(\mathrm{r}=0.856 ; \mathrm{p}$ value $=0.0001)$, length of narcotics use correlated positively and moderately with load family $(r=0.277 ; \mathrm{p}$ value $=0.0001)$. (Table 2$)$ The result of multivariate analysis with multiple linear regressions showed that the age of initial 
narcotics use and drinking alcohol habit (dominant factor) were the factors that could exacerbate the burden of families who have family members of narcotics abusers and experienced relapse. (Table 3 )

Table 1. Demographic characteristics of the respondents

\begin{tabular}{|c|c|c|}
\hline Variables & Frequencies & Percentages \\
\hline Family Members & 111 & 66.07 \\
\hline Parents & 57 & 33.93 \\
\hline Spouse & 3 & 1.8 \\
\hline Education Level & 25 & 14.9 \\
\hline None & 55 & 32.7 \\
\hline $\begin{array}{c}\text { Graduated from } \\
\text { Elementary School }\end{array}$ & 73 & 73.5 \\
\hline $\begin{array}{c}\text { Graduated from Junior } \\
\text { High School }\end{array}$ & 12 & 7.1 \\
\hline $\begin{array}{c}\text { Graduated from High } \\
\text { School }\end{array}$ & 119 & 70.8 \\
\hline Academy / College & 49 & 29.2 \\
\hline Job Status & & \\
\hline Employed & & \\
\hline Unemployed & & \\
\hline
\end{tabular}

Table 2. Correlation between Independent Factors and Family Burden

\begin{tabular}{|c|c|c|}
\hline Variabels & R & P Value \\
\hline Length of narcotics use & 0.277 & 0.0001 \\
\hline The habit of drinking alcohol & 0.956 & 0.0001 \\
\hline The age of initial narcotics use & 0.856 & 0.0001 \\
\hline
\end{tabular}

Table 3. Final Multiple Linear Regression Model

\begin{tabular}{|c|c|c|c|c|}
\hline \multicolumn{5}{|c|}{ Family Burden $=\mathbf{- 3 . 7 9 0}+\mathbf{0 . 4 0 8}$ (The age of initial narcotics use) +2.971 (alcohol drinking } \\
habit) \\
\hline \multicolumn{5}{|c|}{ Model Summary } \\
\hline R & R Square & $\begin{array}{c}\text { Adjusted R } \\
\text { Square }\end{array}$ & $\begin{array}{c}\text { Standart Error } \\
\text { Of The Estimate }\end{array}$ & Durbin Watson \\
\hline 0.964 & 0.929 & 0.928 & 0.567 & 0.982 \\
\hline
\end{tabular}


Families whose members relapsed experienced several disorders while accompanying family members to consume narcotics. This is related to the increasingly heavy burden of the family to be borne. stated that the family burden would get heavier because narcotics addicts were also associated with comorbidities such as tuberculosis and even HIV / AIDS. For this reason, family support is needed by narcotics addicts who experience relapse such as ongoing emotional support. Families can increase the motivation of family members who are addicted and behave positively during the recovery process[20].

A good family function can also suppress the emerging emotional reactions in accompanying family members who have hallucinations[21]. The results of this study revealed that the family burden of narcotics users was getting worse when family members who used narcotics had alcohol drinking habit, age of initial narcotics use and sexual intercourse with an informal spouse, and length of narcotics use.

Based on Assari's research, needle syringe users had more than one sexual partner of about $56.4 \%$, and decreased when the narcotics addict was married. Assari's research proved that married could protect against free sexual intercourse with odds ratio of 0.38 ; and $\mathrm{p}$ value $0.0001[22]$.

The study of Kemp et al., 1998, revealed that the younger the narcotic addicted to sexual intercourse would increase the risk of hepatitis B and C, pulmonary tuberculosis and HIV / AIDs[23]

According to Fassino, a narcotics addict at a young age could lead to personality disorder ${ }^{[24]}$ Narcotics addicts at a young age, both male and female, have the potential to experience physical disorders, mental health disorders and have negative behavior in everyday life such as sexual crimes like rape, public order disturbances and the risk of contracting various sexual diseases. [25] Research done by Alessandra Diel in Brazil revealed that respondents who engaged in risky sexual behavior among non-injecting drug users non-injecting having sex with sex workers with a prevalence ratio of about 1.96, homosexuality and a history of having sex with a prevalence ratio of about 1.39 . This study also revealed that alcohol drinkers and consumption of cocaine risk 2.47 times for having risky sexual behavior compared to non-alcoholic and non-cocaine users.[26] Narcotics users who have alcohol drinking habit should undergo long-term treatment to reduce the dependence [27] The purpose of alcohol dependence treatment is to improve self efficacy so as to have self-belief and efficacy to distance themselves from the dependence[28, 29]

\section{Conclusion}

Narcotics abusers who experience relapse will increase their family burden. Factors that worsen the family burden are age of initial narcotics use and alcohol drinking habit.

\section{Acknowledgments}

We would like to thank Ernaldi Bahar Hospital and the research team who have assisted this research. 


\section{References}

1. BNN. Jurnal Data P4GN. Pencegahan, Pemberantasan Penyalahgunaan dan Peredaran Gelap Narkoba. (Jakarta, 2012)

2. BNNP. Data Penyalahguna Narkotika (Badan Narkotika Nasional Provinsi Sumatera Selatan, 2014)

3. Aquilino WS, Supple AJ. Journal of Family Issues 22, 3 (2001)

4. Barrett AE, Turner RJ. 101, 1 (2006)

5. Friedman AS, Terras A, Glassman K. Journal of Child \& Adolescent Substance Abuse 10, 1 (2000)

6. Karow A, Reimer J, Schafer I, Krausz M, Haasen C, Verthein U. 112, 3 (2010)

7. Ma N, Liu Y, Fu XM, Li N, Wang CX, Zhang H, et al. PloS one 6, 1 (2011)

8. Wang X, Li B, Zhou X, Liao Y, Tang J, Liu T, et al. 126, 3 (2012)

9. Levine HG. International Journal of Drug Policy 14, 2 (2003)

10. Compton WM. Journal of Drug Issues 35, 3 (2005)

11. Dekel R, Benbenishty R, Amram Y. Addictive behaviors 29, 9 (2004)

12. Day A, Doyle P. 15, 5 (2010)

13. Leon G, Staines GL, Perlis TE, Sacks S, McKendrick K, Hilton R, et al. Drug and alcohol dependence 37, 1 (1995)

14. Maehira Y, Chowdhury EI, Reza M, Drahozal R, Gayen TK, Masud I, et al. Harm Reduction Journal 10, 1 (2013)

15. Domino KB, Hornbein TF, Polissar NL, Renner G, Johnson J, Alberti S, et al. 293, 12 (2005)

16. Hasin D, Liu X, Nunes E, McCloud S, Samet S, Endicott J. Archives of General Psychiatry.;59, 4 (2002)

17. Donovan D MM, Cisler RA, Longabaugh R, Zweben A. J Stud Alcohol (2005)

18. Rasmussen S. Addiction Treatment, Theory and Practise (London, Sage Publication, 2000)

19. Thornton M, Travis SS. Analysis of the reliability of the modified caregiver strain index. The journals of gerontology Series B, Psychological sciences and social sciences 58, 2 (2003)

20. Saunders JC. Families living with severe mental illness: a literature review. Issues Ment Health Nurs.;24(2):175-98 (2003)

21. Teschinsky U. Issues in Mental Health Nursing. 21, 4 (2000)

22. Assari S, Yarmohamadivasel M, Narenjiha H, Rafiey H, Noori R, Shirinbayan P, et al. Frontiers in Psychiatry 5 (2014)

23. Kemp R, Miller J, Lungley S, Baker M. The New Zealand medical journal 111 (1998)

24. Fassino S, Daga GA, Delsedime N, Rogna L, Boggio S. Drug and alcohol dependence 76, 1 (2004)

25. Karow A, Reimer J, Schäfer I, Krausz M, Haasen C, Verthein U. Drug and alcohol dependence 112. 3 (2010)

26. Diehl A, Vieira DL, Rassool GH, Pillon SC. Adicciones: Revista de socidrogalcohol. 26, 3 (2014) 
27. McKay JR. 100, 11 (2005)

28. Bogenschutz MP, Tonigan JS, Miller WR. Journal of Studies on Alcohol 67, 4 (2006)

29. Ilgen M, McKellar J, Moos R. Journal of Studies on Alcohol and Drugs 68, 1 (2007) 